\title{
ANALYSIS OF PROFITABILITY OF SMALLHOLDER IRRIGATED FOOD PLOTS IN THE EASTERN CAPE PROVINCE OF SOUTH AFRICA
}

\author{
Lelethu Mdoda ${ }^{1}$, Ajuruchukwu Obi ${ }^{1}$
}

${ }^{1}$ University of Fort Hare, South Africa

\begin{abstract}
Smallholder irrigation farming is transformative to poor households as it improves livelihoods and alleviates poverty. However, little has been done to quantify its profitability. Therefore, the present study assessed the profitability of smallholder irrigated crop farmers in the Eastern Cape province of South Africa and ascertained its determinants. A multistratified technique was employed to select 120 smallholder irrigated crop farmers. Data was analyzed using gross margin and multiple regression models. The results showed that crop production is profitable. Farm experience, years spent in school, access to credit, distance to markets, and tractor use were found to have a bearing on the profitability of irrigated crop farmers. Based on the results, crop farming was identified to be crucial for jobs creation and poverty reduction.
\end{abstract}

Keywords: smallholder, homestead gardeners, irrigated, profitability, Eastern Cape

\section{INTRODUCTION}

Agriculture remains crucial in the economic, political and social systems of the developing world, and evidently is the major building block in attaining the Sustainable Development Goals (SDGs) for 2030. Unsurprisingly, the majority of the world's poor directly and indirectly depend on agricultural production for survival (Fitcher and Quaim, 2012). Within agriculture, crop production stands out as an important point of entry for low-skilled and resource-poor households for whom vegetable sources of protein and other essential nutrients are more affordable than those from animal sources (Samboko, 2011). Expectedly, many African economies are prioritizing agriculture and taking urgent steps to enhance its productivity especially in the smallholder sector (Koranteng, 2010). But the concern remains that for the vast majority of these developing countries, abundant supply of arable land and water has not translated to enhanced self-sufficiency in food production and income generation due to the underutilization of arable land and low productivity (UNCTAD, 2009).

For South Africa, the period since the end of the apartheid rule has witnessed increased government support for smallholders. The sad reality is that, despite government efforts to empower these smallholder farmers and enhance their livelihoods, the transition from subsistence to commercial farming remains slow, leading to increased food insecurity and widespread poverty among rural communities (Ramaila et al., 2011). As a result of this slow pace, attention has focused on survival strategies rather than on profitability growth in the sector, a situation that perpetuates the poor performance that characterizes the smallholder sector. In recent years, government has shifted its focus to the promotion of innovation and adoption of new technologies such as irrigation farming as a sure way of enhancing smallholder production, reducing poverty and restoring livelihood to

\footnotetext{
$\llbracket$ Lelethu Mdoda, PhD, Department of Agricultural Economics and Extension, University of Fort Hare, Private bag X1314, Alice, Eastern Cape, Alice, 5700, South Africa, e-mail: lelethu.mdoda@gmail.com, https://orcid.org/0000-0002-5402-1304
} 
smallholder farmers. The conventional wisdom is that participation of smallholder farmers in market-oriented production has potential for income diversification and increase in agricultural productivity which leads to enhanced profitability, food security and poverty reduction. But in the midst of numerous farming challenges, market participation has failed to be transformative for households and farmers. As a consequence, economic welfare has declined in recent years.

Without a doubt, the almost exclusive focus on overcoming the constraints to market participation has equally deflected research priorities away from consideration of the critical question of farm profitability and the factors that condition it in the smallholder irrigation schemes. In fact, the majority of these studies dwell disproportionately on market participation and its causes and implications. Profitability is important for agricultural development but is influenced by several factors that need to be understood. At a basic level, it is imperative that farmers produce for markets in order to earn farm profits which explains the formulation of policies to enhance market access for smallholders. In addition, the imperfections in information markets escalate costs of locating reliable information, leading to considerable welfare losses for participants and erecting barriers to entry for others, which in turn influences profit levels for farmers. It is in this light that this study assesses profitability and its determinants among smallholder irrigated crop farmers and homestead gardeners in the Eastern Cape province. The paper is structured as follows: after this introduction, it describes the study area before presenting the model and conceptual framework, and the study methodology. The results and discussions then follow, and the paper winds up by drawing the main conclusions and proffering a set of recommendations.

\section{MATERIALS AND METHODS}

\section{Study area}

The study was carried out in the Eastern Cape province which is the third most populated province in South Africa with 6,562,053 (12.7\%) after Gauteng and KwaZulu Natal provinces, which are estimated to have populations of $12,272,263$ million ( $23.7 \%$ of national) and 10,267,300 (10.8\%), respectively (Hlomendlini, 2015; Scarr, 2013). The province is made up of 5 districts and 2 metropolitan municipalities. The average poverty level of the province was estimated at $74.9 \%$ (Stats SA,
2013 ) and the province's level of food insecurity (78\%) is above the national average of $64 \%$, making households in the province some of the most food insecure in the country (Scarr, 2013). The majority of the residents derive their livelihoods from agriculture. Hlomendlini (2015) stated that a large percentage of households in the province who are involved in farming are in most cases not farming for business and income. Instead, they practice farming to supplement other income sources and for household subsistence purposes.

The province is richly endowed with natural resources ranging from luscious grazing lands and pastures to forests; from marine life to rich farming soils; and from water to wilderness. The province has all the seven of South Africa's ecological zones and the province's climate is favorable for agricultural production. Crop production currently practiced in the province includes the production of vegetables, chicory, maize, tomatoes and pineapples which are successfully cultivated. The province has abundant water from the numerous rivers that run from the mountains to the sea. The study adopted a cross-sectional survey design where the data was collected at one point in time with the use of structured questionnaires.

\section{The empirical model}

This study investigates profitability and its determinants within the irrigated smallholder cropping system of the Eastern Cape province of South Africa. Seen as the link between costs and revenue within the farmer's enterprise, the critical need is to derive a means for aggregating the farmers' costs and their returns and establishing the difference between these figures. In the context of the ongoing transformation in the country, the determinants of profitability are crucial ingredients for policy. Hence, the present study must adopt a procedure that is at once descriptive and depicting cause-effect relationships. The Gross Margin Analysis and Multiple Regression Model satisfy this requirement to measure profitability and its determinants in crop production in the study area. The Gross Margin Analysis is widely used to evaluate an enterprise's economic viability. It is mostly used in agriculture for planning and comparison of farmers who share similar characteristics within their enterprise. The formal model is generalized as:

$$
\mathrm{GM}(\pi)=\Sigma\left(\mathrm{TR}_{i}-\mathrm{TVC}_{i}\right)
$$

where: 
GM - means gross margin per irrigated crop.

TR is the total revenue from production of crop $i$ measured in terms of

TVC is the total variable cost of the production of crop i, measured in terms of direct and indirect costs. This includes transport, water, hired labor, seed, chemicals and fertilizers.

The total revenue, which is equivalent to crop income or gross income from each crop, was calculated as:

$$
\mathrm{TRi}=P_{i} \times Q_{i}
$$

Where:

$P_{i}-$ is the farmgate price of crops,
$Q_{i}-$ is the total quantity produced for each crop.

Total variable costs were calculated using the following expression:

$$
\mathrm{TVC}=\sum_{i=1}^{2}\left(K_{i t}+S_{i t}+L_{i t}\right)
$$

Where:

$K_{i t}-$ is the fertilizer expenditure,

$S_{i t}-$ is the total expenditure on seed,

$L_{i t}$ - is the total labor expenditure in each enterprise.

The paper further calculated the Net Farm Income after gross margin calculations as it includes land, capital and management. The NFI is the product of production costs and gross margin. This method provides important information about the results of operating activities over a given period. The NFI is often described in aggregate terms and is an influential and highly exposed statistic when used to describe the fitness of the farming sector (Tshiame, 2013). It is helpful to include Net Farm Income in profit estimation as it takes into account the farmer's production costs.

$$
\begin{gathered}
\text { Gross Margin }=\text { Total Revenue (TR) }- \\
- \text { Total Variable Costs (TVC) }
\end{gathered}
$$

From the above equation, Net Farm Income is derived as shown below:

$$
\mathrm{NFI}=\mathrm{GM}-\mathrm{TFC}
$$

Where:

NFI - is the Net Farm Income/Profit

$\mathrm{GM}$ - is the farm gross margin

$\mathrm{TFC}$ - is the total fixed cost of the farm

\section{Determinants of profitability}

The multiple regression model was used to examine the determinants of profitability among irrigated crop farmers. The goal is to estimate and model the relationship between the set of hypothesized causal variables to understand their influence over the profitability of the enterprise. This is well handled by regression analysis (Gujarati, 1992) as depicted by the following relations:

$$
Y=f \sum_{i=1}^{n} X_{1}, X_{2}, \ldots, X_{n}
$$

Following conversion, the model can be specified as:

$Y=\beta_{0}+\beta_{1} X_{1}+\beta_{2} X_{2}+\beta_{3} X_{3}+\beta_{4} X_{4}+\ldots+\beta_{n} X_{n}+\mu_{\mathrm{i}}$

where:

$\beta_{0}$ - intercept term,

$\beta_{1}, \beta_{2}, \beta_{3}, \beta_{4} \ldots-$ regression coefficients,

$X_{1}, X_{2}, X_{3}, X_{4} \ldots-$ explanatory or independent variables,

$\mu_{\mathrm{i}}$ - error or disturbance term.

\section{Data}

The data is presented in Table 1 and explained below.

\section{Data collection}

The study was undertaken in the Eastern Cape province of South Africa, within three District Municipalities of the province. The Districts are well-known for their large areas of good crop land and soils which also supports livestock farming. A multi-stage sampling procedure was employed by which smallholder irrigation schemes in the Eastern Cape were purposively selected and within which 120 food plot-holders were enumerated.

The study implemented a systematic and multipronged data collection procedure. Data was collected through a single-visit farmer survey and a household survey using a structured questionnaire. The respondents were interrogated on production costs; yields; prices; target markets; social, and economic and farm characteristics of smallholder crop farmers growing cabbage, spinach, maize and pumpkins. The information varied from household to household. The questionnaire was structured in such a way that the first part covers the socioeconomic variables such as age of the household head, household size, off-farm income, gender etc. The second part dealt with the productive inputs such as land, labor, cost of tractor hours and use of materials such as fertilizers and seed. Table 1 above presents the relevant data collected by this process. Data entry, data 
Table 1. Hypothesized influential factors of profitability

\begin{tabular}{llc}
\hline \multicolumn{1}{c}{ Dependent variable } & \multicolumn{1}{c}{ Description } & Anticipated sign \\
\hline Profit (gross margin) & Continuous & Anticipated sign \\
\hline \multicolumn{1}{c}{ Independent variable } & \multicolumn{1}{c}{ Description } & + \\
\hline Age & Discrete (years) & $+/-$ \\
Gender & Categorical: male $=1$, female $=0$ & $+/-$ \\
Marital status & Dummy: married = 1; otherwise $=0$ & $+/-$ \\
Highest educational level & Discrete (years of school attendance) & $+/-$ \\
Household size & Discrete (number) & $+/-$ \\
Family size & Categorical & $+/-$ \\
Extension services & Categorical & $+/-$ \\
Arable land & Discrete (ha) & $+/-$ \\
Employment status & Categorical: employed = 1, unemployed $=2$ & $+/-$ \\
Farming experience & Discrete (years) & + \\
Source of income & Discrete (ZAR) & + \\
Membership in farm organization & 1 = member of an organization & \\
& $0=$ otherwise &
\end{tabular}

Source: own calculations.

cleaning, management of missing data and descriptive analysis were done using SPSS software.

\section{RESULTS AND DISCUSSION}

This section presents the descriptive statistics of the variables and the estimation results of gross margin and multiple regression. The results cover the determination of profitability and the factors that influence profitability of smallholder irrigated food plots in the study area.

\section{Socioeconomic profiles of irrigated crop farmers}

The study results indicated that most farm households are headed by males (in the proportion of $68.5 \%$ males to $31.5 \%$ females). The average age of the household head among smallholder irrigators is 60 years. This means that agriculture in the study areas is dominated by elderly people, probably because of mass retrenchments at the mines in the wake of mechanization of mining operations that began in 2010 (Kibirige, 2013). Smallholder crop irrigators are mostly literate as the majority of the respondents have primary education, having spent approximately 5 years in school; only a handful of respondents did not have any kind of education. Household size averaged 5 persons. Farming experienced was 11 years on average. The study revealed that $68 \%$ of farmers are members of farm organizations. Most respondents (70.1\%) earned between ZAR 600 and ZAR $1,000.00$ while $4.7 \%$ earned above ZAR 1,000-ZAR 5,000.

\section{Gross margin estimates of smallholder irrigated crop farmers}

The results of the gross margin and net farm income analyses are presented in Table 2.

A total of USD 22,664.66 was received by smallscale food plot farmers.

The results show that Gross Margin and Gross Profit Margin stood at USD 22,664.66. The positive Gross Margin indicates that smallholder irrigated crop farmers in the Eastern Cape province generate sufficient income, on average, to support their households. The profit ratio was found to be 1.47 , meaning that for every USD 1 
Mdoda, L., Obi, A. (2019). Analysis of profitability of smallholder irrigated food plots in the Eastern Cape province of South Africa. J. Agribus. Rural Dev., 3(53), 225-232. http://dx.doi.org/10.17306/J.JARD.2019.01265

Table 2. Profitability of crop enterprises among smallholder irrigators

\begin{tabular}{lrrrrr}
\hline \multirow{2}{*}{ Crop produced } & \multicolumn{1}{c}{ TR } & TVC & Gross margin (USD) & $\begin{array}{c}\text { RRI } \\
\text { (GM/TVC) }\end{array}$ \\
\cline { 2 - 3 } Maize & \multicolumn{2}{c}{ (USD/ha) } & & 10318.50 & 1.08 \\
Cabbage & 19850.41 & 9531.91 & 3531.51 & 1.11 \\
Spinach & 6705.02 & 3173.51 & 2737.01 & 3.33 \\
Potatoes & 3557.95 & 820.94 & 6077.64 & 3.28 \\
Overall gross margin & 7928.03 & 1850.40 & 22664.66 & 1.47 \\
\hline
\end{tabular}

Gross margin (USD) 22664.66

Less fixed cost (rent land, depreciation of farm assets and farm tools)

Total fixed costs (USD) 5282.53

Net farm income (USD) 17382.13

TR - Total revenue; TVC - Total variable cost; RRI - Returns per Rand Invested.

Source: field survey, 2017.

spent on food plots in the production of any of the four crops (maize, potatoes, cabbage and spinach), farmers stand to make a profit of USD 1.47. Thus, scheme farmers in the Eastern Cape province are able to cover their production costs and make profit from the sales of their products. Farm profitability can also be expressed in terms of Net Farm Income (NFI) which is obtained by deducting the Total Variable Cost (TVC) from the
Total Revenue (TR), i.e. NFI $=$ TR - TVC. As previously explained, the TVC was calculated by adding up all the farm expenditure (fertilizer, total labor and total seeds) used.

In order to determine the factors influencing profitability of irrigated food plot farming, a multiple regression model was estimated. The results are presented in Table 3 .

Table 3. Factors influencing profitability of smallholder irrigated crop farmers in the Eastern Cape province

\begin{tabular}{lccc}
\hline \multicolumn{1}{c}{ Variable } & Coefficient $\beta$ & T statistics & Significant \\
\hline Age & -0.205 & -1.675 & $0.028^{*}$ \\
Years in school & 0.199 & 1.814 & $0.014^{*}$ \\
Off-farm income & -0.242 & -1.951 & $0.015^{*}$ \\
Road condition & 0.224 & 1.889 & $0.002^{*}$ \\
Access to credit & -0.212 & 1.911 & $0.000^{* *}$ \\
Distance to markets & 0.205 & 1.981 & $0.001^{*}$ \\
Constant & -0.438 & -1.102 & 0.274 \\
\hline
\end{tabular}

$F$-value 12.45

$R$-squared 0.6320

Adjusted $R$-squared 0.6032

Observations 120

Note: $* *$ and $*$ are significant at $1 \%$ and $5 \%$, respectively.

Source: field survey, 2017 
The explanatory variables were quantified as those related to socioeconomic factors of smallholder irrigated food plot farmers in the Eastern Cape province. For all the variables with a positive coefficient, it implies that as any of them increases, so does farm profitability. Table 3 summarizes the empirical results of multiple regression. As can be seen, the farmers' age has a negative coefficient and is significant at $5 \%$. The negative coefficient implies an inverse proportional relationship with profitability. Also, it suggests that elderly people tend not to participate in markets to the same extent as younger farmers. From the results, a $1 \%$ increase in age of the farmers will induce a decrease in farm profitability by $0.205 \%$. Since profitability is likely to be strongly influenced by the size of farm output and by how efficiently the output is delivered, physical fitness and time preference, among other considerations, may become important; these are factors largely influenced by age. It was suggested elsewhere that older farmers are less likely to "introduce new, transformative productive techniques" that lead to enlarged output and greater efficiencies (Vos, 2019). Older farmers may also be less eager to expand and market their output; according to Randela et al. (2008), older farmers tend to view farming more as a way of life rather than as business. Hence, they may tend to visit the market less frequently or produce smaller marketable surpluses than younger persons.

As can be seen in Table 3, the number of years spent in school had a significant and positive influence on farm profitability at a $5 \%$ level. This suggests that the more years spent in school, the more competitive a farmer becomes. The study revealed that a unit increase in the number of years spent in school will induce an increase in farm profitability by $0.199 \%$. Off-farm income has a negative significant influence on farm profitability at a $5 \%$ level. Thus, a $1 \%$ increase in off-farm income of smallholder irrigated crop farmers will induce a decline in farm profitability by $0.242 \%$. This probably means that the more the farmer relies on off-farm income (which means a considerable extent of moonlighting), the smaller the profit generated in the farm.

Road condition has a significant positive relationship with farm profitability at a $1 \%$ level. The positive coefficient suggests that a direct relationship exists between road condition and farm profitability since better road conditions would normally mean easier and less costly access to markets. The distance to markets had a positive significant relationship with farm profitability at $1 \%$. This implies that a $1 \%$ increase in distance will induce an increase in farm profitability by $0.205 \%$. The farther the markets, the higher the returns from crop sales by farmers, evidently because the farmers earn a premium for adding spatial utility to the commodity.

Access to credit has a negative significant relationship with farm profitability at a $1 \%$ level. Thus, a $1 \%$ increase in access to credit by farmers will induce a decrease in farm profitability by $0.212 \%$. Insufficient access to credit by smallholder farmers has an adverse effect on farm profitability because it could compel farmers to use outdated technologies for their farming due to improved inputs being unaffordable. The results corroborate the conclusions of Balana et al. (2015) that smallholder farmers are credit-constrained in their farming. When the overall model fitness was tested, it was found that the $\mathrm{R}^{2}$ is $63.20 \%$, the adjusted $\mathrm{R}^{2}$ is $60.32 \%$ and the F statistic is 12.45 , suggesting that much of the hypothesized relationship is supported by the findings.

\section{CONCLUSION AND RECOMMENDATION}

The purpose of this study was to assess profitability and its determinants among smallholder irrigated crop farmers and homestead gardeners in the Eastern Cape province. The study showed that maize, potatoes, spinach and pumpkins are the most frequently cultivated crops by smallholder farmers in the study area. Farming in the province is dominated by male farmers with an average age of 60 years. The study revealed that crop farmers sourced their information from farmer associations as most of them are members of farmer associations and have access to extension services. Based on the findings of the study, it can be concluded that crop production is profitable and is capable of improving the standard of living for the people. With the current prevailing market conditions for inputs and output, farmers were able to recover the cost of production and remain profitable. Production largely depends on profitability which provides an incentive for the farmers and enables them to expand output and earn even higher economic returns on resources invested, including land and labor. It can be concluded that increased profitability depends on years spent in schools, access to credit, access to extension services, road conditions, distance to markets and age of the farmers. Developing market infrastructure, providing production assistance and encouraging small 
farmers to associate to form farmer groups will undoubtedly contribute to enhanced profitability and speed up the transition from subsistence farming to commercialized market-oriented agriculture.

\section{ACKNOWLEDGEMENT}

The authors sincerely acknowledge the financial assistance of the Water Research Commission (WRC) and the NRF DAAD In-Country Scholarship Scheme.

\section{REFERENCES}

Abdulai, A., Huffiman, W. (2000). Structural adjustment and economic efficiency of Rice Farmers in Northern Ghana. Eco. Dev. Cul. Cha., 48, 503-520.

Adesina, A., Djato, K. K. (1997). Relative efficiency of women as farm managers: Profit function analysis in Cote d'Ivoire. Agric. Econ., 16, 47-53.

Balana, B., Mul, M., Williams, T. O., Ghansa, B., GyamfuahOwusu, A., Amarnath, G. (2015). Analysis of Historical Flood Inundation and Recession Patterns: Implications for Flood Recession Agriculture in Northern Ghana. Unpublished project progress report.

Baiyegunhi, L. J. S., Fraser, G. C. G. (2009). Profitability in Sorghum Production in Three Villages of Kaduna State Nigeria. J. Appl. Sci. Res., 10, 1685-1691.

Berger, A. N., Mester, L. J. (1997). Inside the black box: What explains differences in the efficiencies of financial institutions? Financial Institutions Center. Retrieved from: http://citeseerx.ist.psu.edu/viewdoc/download?doi=10.1 $1.41 .573 \&$ rep $=$ rep $1 \&$ type $=$ pdf

Coelli, T. J. (1995). Estimators and hypothesis tests for a stochastic frontier function: A Monte Carlo analysis. J. Prod. Anal., 6, 247-268.

Chidi, I., Anozie, R. O., Priscilia, N. C. (2015). Analysis of socio-economic factors and profitability of rice production among small-scale farmers in Ebonyi State. J. Agric. Vet. Sci., 8(2), 20-27.

Christian, M. (2015). Assessing the impact of primary agricultural co-operative members on smallholder farm performance (crops) in Mquma Local Municipality in the Eastern Cape province. Published MSc Dissertation, University of Fort Hare, Alice, South Africa.

Cousins, B. (2013). Smallholder Irrigation Schemes, Agrarian Reform and 'Accumulation from Above and from Below' in South Africa. J. Agrar. Change, 13(1), 116-139.

ECDRAR (Eastern Cape Department of Rural Development and Agrarian Reform). (2012). Annual Operation Plan 2012-2013. Bisho, Eastern Cape Provincial Government.
EDEAT (Economic Development, Environmental Affairs and Tourism). (2000-2010). The Eastern Cape, Adventure province essence of Province's heart. Retrieved Nov 23rd 2018 from: http://www.dedea.gov.za/Lists/About $\% 20$ the $\% 20$ Eastern $\% 20$ Cape/AllItems.aspx\#

ECDC (Eastern Cape Development Corporation). (2013). About the Eastern Cape: District Maps. Retrieved 15th May 2019 from: http://www.ecdc.co.za/the_eastern_cape/ district_map

ECDC (Eastern Cape Development Corporation). (2007). Introduction to the Eastern Cape. Retrieved 15th May 2019 from: http://www.ecdc.co.za/easterncape

Ergano, K., Nurfeta, A. (2006). Economic performance of case study dairy farm in Southern Ethiopia. Liv. Res. Rur. Dev., 18(8). Retrieved 6 ${ }^{\text {th }}$ Nov 2018 from: http://www. lrrd.org/lrrd18/1/erga18008.htm

Fanadzo, M., Chiduza, C., Mnkeni, P. N. S. (2009). Comparative response of direct seeded and Transplanted Maize (Zea mays 1.) To Nitrogen Fertilization at Zanyokwe Irrigation Scheme, Eastern Cape, South Africa. Afr. J. Agric. Res., 4(8), 689-694.

Fischer, E., Qaim, M. (2012). Linking Smallholders to Markets: Determinant and Impacts of Farmer Collective Action in Kenya. World Dev., 40(6), 1255-1268.

Gabaye, P. (2013). An Assessment of the Profitability of Small Holder Commercial Egg Production in Zimbabwe. A Case Study of Goromonzi, UMP and Mutasa Districts. Published MSc Dissertation, University of Zimbabwe, Zimbabwe.

Gidi, L. S. (2016). Paths for establishing entrepreneurship with livelihood strategies to enhance food security, profitability and employment opportunities of rural households on smallholder irrigation schemes in Eastern Cape Province, SA. Unpublished PhD Thesis, University of Fort Hare, RSA.

Gujarati, D. (1992). Essentials of Econometrics. London: McGraw-Hill.

Hlomendini, P. H. (2015). Key factors influencing smallholder market participation in the former homelands of South Africa: Case study of Eastern Capr. MSc Thesis, Stellenbisch University, South Africa. Unpublished.

Kay, R. D. (1986). Farm Management, Planning, Control and Implementation (pp. 65-126). London: McGraw Hill.

Kebede, B. (2016). The analysis of productivity and the profitability of smallholder potato growers in bore district, Guji Zone, Oromia Region, Ethiopia. Published MSc Thesis, Haramaya University, Haramaya, Ethiopia.

Kibirige, D. (2013). The impact of human dimensions on smallholder farming in the Eastern Cape Province of South Africa. Published Thesis, University of Fort Hare, Alice, South Africa. 
Kolawole, O. (2006). Determinants of profit efficiency among small scale rice farmers in Nigeria: a profit function approach. Poster paper prepared for presentation at the International Association of Agricultural Economists Conference, Gold Coast, Australia, August 12-18, 2006.

Koranteng, K. Y. (2010). Contract farming model of financing smallholder farmers in South Africa: The case of the IDCKat river citrus development scheme. Published Masters Dissertation, University of Stellenbosch, RSA.

Makhura, T. M. (2001). Overcoming transaction costs barriers to market participation of smallholder farmers in the Northern Province of South Africa, Unpublished $\mathrm{PhD}$. thesis, University of Pretoria. South Africa.

Mmbando, F. E. (2014). Market participation, channel choice and impacts on household welfare: The case of smallholder farmers in Tanzania. Published PhD Thesis, University of KwaZulu-Natal, Pietermaritzburg, South Africa.

Maudos, J., Pastor, J. M., Perez, F., Quesada, J. (2002). Cost and Profit Efficiency in European Banks. J. Int. Fin. Mar. Int. Mon., 12, 33-58.

Mokgalabone, M. S. (2015). Analyzing the technical and allocative efficiency of small-scale maize farmers in Tzaneen Municipality of Mopani District: A Cobb-Douglas and Logistic Regression Approach. Published M Dissertation, University of Limpopo, Limpopo, RSA.

Mujuru, N. M. (2015). Modeling irrigated smallholder crop enterprises in the Eastern Cape Province of South Africa with emphasis on profit efficiency and food security. Unpublished PhD Thesis, University of Fort Hare, Alice, South Africa.

Nyekanyeka, T. (2011). Analysis of Profitability and Efficiency of Improved and Local Smallholder Dairy Production: A Case of Lilongwemilk Shed Area. Published MSc Thesis, University of MalawI, Bunda College, Malawi.

Obi, A., Pote, P. (2012). Technical constraints to market access for crop and livestock farmers in Nkonkobe Municipality, the Eastern Cape Province. In: A. Obi, H. D. Van Schalkwyk, J. A. Groenewald, G. C. Fraser and A. Van Tilburg (Eds.), Unlocking markets to smallholders: Lessons from South Africa. Wageningen: Wageningen Academic Publishers.

Oluwatayo, I. B., Machethe, T. A., Senyolo, M. P. (2016). Profitability and efficiency analysis of smallholder broiler production in Mopani district of Limpopo Province, South Africa. J. Agribus. Rural Dev., 1(39), 145-154.

Onoja, A. O., Deedam, N. J., Achike, A. I. (2012). Profitability and yield determinants in Nigerian cocoa farms: Evidence from Ondo State. J. Sust. Dev. Afr., 14(4), 172-182.
Osondu, C. K., Ijioma, J. C. (2014). Analysis of profitability and production determinants of fish farming in Umuahia Capital Territory of Abia State, Nigeria. World J. Agric. Sci., 2(7), 168-176.

Ramaila, R., Mahlangu, S., Toit, T. (2011). Agricultural productivity report in South Africa literature review. Department of Agriculture, Forestry and fisheries, Directory Economic Service, Production Economics Unit.

Randela, R., Alemu, Z. G., Groenewald, J. A. (2008). Factors enhancing market participation by small-scale cotton farmers. Agrekon, 47(4), 451-469.

Samboko, P. C. (2011). An assessment of factors influencing the profitability of bean production in Zambia. Lusaka: University of Zambia.

Samuelson, P. A., Nordhaus, W. A. (2005). Economics. New Delhi: Tata Mc-Graw-Hill.

Scarr, N. (2013). 2013/14 Budget Analysis. Chief Directorate: Environmental Affairs. Eastern Cape Department of Economic Development, Environmental Affairs \& Tourism.

Shalma, H. J. (2014). Economic analysis of soya bean production under Sasakawa Global 2000 Project in Kaduna State, Nigeria. Zaria: Ahmadu Bello University.

Stats SA (2012a). Census 2011 Provinces at a glance. Pretoria: Statistics South Africa.

Stats SA (2012b). General Household Survey Series Volume IV. Food Security and Agriculture (2002-2011): In Depth analysis of General Household Survey. Pretoria: Statistics South Africa.

Tshiame, M. I. (2013). Productivity and profitability measures of emerging farm enterprises in the Mpumalanga Province. Pretoria: Tshwane University of Technology.

UNCTAD (United Nations Conference on Trade and Development) (2009). World investment report. Transnational Corporations, Agricultural Production and Development. New York, Geneva: United Nations.

Vos, R. (2019). Is global food security jeopardised by an old age timebomb? Guardian Professional \& the Strategic Programme on Rural Poverty Reduction. Guardian. Retrieved May $5^{\text {th }} 2019$ from: https://www.theguardian.com/ global-development-professionals-network/2014/feb/04/ global-food-security-old-age-timebomb.

Young, J. (2013). Investing in the Eastern Cape. Brand South Africa Retrieved October 15 2018 from: https://www. brandsouthafrica.com/investments-immigration/business/ investing/opportunities/investing-in-the-eastern-cape

Zulu, E. T. (2011). Profitability of Smallholder Cowpea Production in Zambia. Lusaka: University of Zambia. 